\title{
Design and Manufacture of 6 Axis Forces and Moments Transducers for Seaplane Floaters Test in Towing Tank
}

\author{
Nurhadi $^{\mathrm{a}, *}$, Mochammad Nasir ${ }^{\mathrm{b}}$, Chandra Permana ${ }^{\mathrm{c}}$, Endah Suwarni ${ }^{\mathrm{d}}$ \\ a'Laboratory for Hydrodynamics Technology, BPPT. Email: nrhadi@gmail.com \\ bLaboratory for Hydrodynamics Technology, BPPT. Email: nasir08.1hi@gmail.com \\ cLaboratory for Hydrodynamics Technology, BPPT. Email: chandra.pzm@gmail.com \\ ${ }^{\mathrm{d}}$ Laboratory for Hydrodynamics Technology, BPPT. Email: endahsuwarni@ gmail.com
}

\begin{abstract}
To develop seaplanes as a means of inter-island transportation, it is necessary to have a simulation, testing, and analysis of force measurements that work so that the aircraft can be designed optimally in terms of function and safety. To fulfill one type of test, the seaplane floater model is pulled in the Towing Tank to determine the hydrodynamic forces acting on the floater which include resistance $(F x)$, side force $(F y)$, lift force $(F z)$, and moments in all three axes. A method of measuring the force of 6 axis force and moment or 6 degrees of freedom (6 Degree of Freedom, 6 DOF) was built and designed by combining several single load cells so that these forces can be known optimally. From the results of the 6 DOF transducer design, it is proven that it can be used well in measuring 6 forces and moments with force measurement errors ranging from $1.38 \%$. The distance between the $6 \mathrm{DOF}$ transducer capture point and the floater force capture point will affect the measured moment transformation.
\end{abstract}

Keywords: 6 degree of freedom; floater; towing tank; transducer design

\section{Introduction}

One of the proper transportation models developed in Indonesia as an archipelago is a transportation that can be used both on land, air, and water such as seaplanes. Seaplanes are airplanes that can air from land or from the surface of the water and can return to land or to the surface of the water. One type of seaplane is a floatplane or seaplane where the aircraft uses additional components in the form of a floater to float while the fuselage is above the surface of the water. This transportation system will be very flexible because it can cover the land (airstrips), large lakes and rivers, bays, seas, and waters among islands that have calm seas, which allow for takeoff and landing for amphibious aircraft throughout the year. This transportation is much easier and cheaper than building airports in general.

In the design and development of seaplanes, they should not be careless because they are related to safety so an analysis of the forces that work both on the fuselage and the floater is needed. To know the forces, of course, it can be done using simulation [1] and through measurement analysis using force sensors [2].

\footnotetext{
* Corresponding author. Tel.: +62811328567

Jl. Hidrodinamika, Kompleks ITS, Sukolilo, Surabaya, 60111
}

Seaplanes will run at high speed from start to 60 knots when taking off, especially on the water so that the hydrodynamic forces will work due to the friction of the floater with water. Because of the hydrodynamic forces so it will be important to know the amount of resistance and the amount of lift force of the floater and the moments that work that will facilitate the control of the seaplane. With the existence of these forces, in addition to simulations and aerodynamic tests [3], the simulation and testing of the floater model to determine the hydrodynamic forces are very important to do.

In testing the seaplane floater model in the Towing tank, a measuring instrument should capture the hydrodynamic forces acting on the floater. These forces include resistance $(F x)$, side forces $(F y)$, lift $(F z)$, as well as moments in the three-axis directions. A method of measuring the force of 6 degrees of freedom (6 Degree of Freedom, 6 DOF) requires a special design to obtain an optimal value following their needs [4]. For this reason, it is necessary to design a transducer by utilizing six $\mathrm{S}$ type load cells which are arranged in such a way as to form six-component transducers. With six-component transducers, it is expected that the forces of $F x, F y, F z$, and the moments of $M x, M y$, 
$\mathrm{Mz}$ that occur on the floater when pulled will be known optimally.

\section{Literature Review}

\subsection{Strain and sensors applications}

A strain sensor is a passive transducer that uses the concept of changing the electrical resistance in a metal wire to change every pull produced by the force that hits the wire. The concept of this change can be used to measure weight, pressure, and mechanical force. Strain sensors are made of one long wire, folded, and placed on a soft or flexible material [5]. Any force, strain, applied to the area where the strain gauges are attached will cause a change in the length and cross-sectional area of the wire as shown in Fig. 1.

This change will result in a change in the resistance of the wire itself through the connection:

$$
R=\frac{\rho . l}{A}
$$

$$
\begin{aligned}
& R=\text { wire resistance }(\Omega) \\
& \rho=\text { wire resistance coefficient }(\Omega-\mathrm{m}) \\
& l=\text { wire length }(\mathrm{m}) \\
& A=\text { wire cross-sectional area }\left(\mathrm{m}^{2}\right)
\end{aligned}
$$

The relationship between strain and force (load) can be calculated by the formula:

$\operatorname{Strain}(\varepsilon)=\frac{\text { change of wire length due to the load }(\partial l)}{\text { wire length }(l)}$

Based on the principle of changes in strain values due to forces, by using 4 strain gages which are connected in the full-bridge, the value of a strain that occurs due to changes in force acting can be measured.

In Fig. 2, if the load cell has a force $F$, there will be a strain on the R-value of the strain gages mounted with the change in the value of $R$ is:

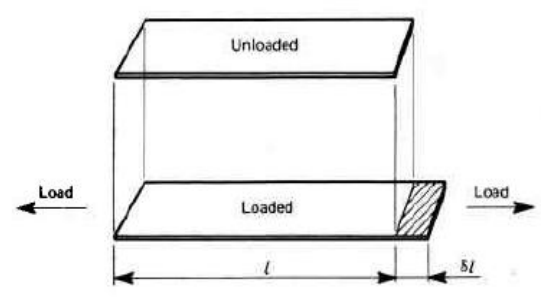

Figure 1. Principle of strain gages sensor [5]



F

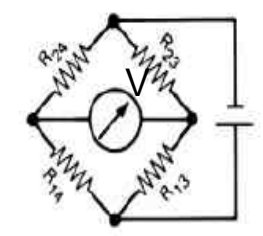

E

Figure 2. Strain sensor application with the full-bridge relationship [5]

$$
\begin{aligned}
& R 24 \text { increases to } R+\delta R \\
& R 13 \text { increases to } R+\delta R \\
& R 14 \text { is reduced to } R-\delta R \\
& R 23 \text { is reduced to } R-\delta R
\end{aligned}
$$

So that

$$
\begin{aligned}
& i_{24}=\frac{E}{R_{24}+R_{14}}=\frac{E}{R+\partial R+R-\partial R}=\frac{E}{2 R} \\
& V_{24}=i_{24 .} R_{24}=\frac{E}{2 R}(R+\partial R) \\
& V=V_{23}-V_{24}=\frac{E R-E \partial R}{2 R}-\frac{E R+E \partial R}{2 R} \\
& V= \pm \frac{E \partial R}{R}
\end{aligned}
$$

By comparing the output voltage generated due to the forces acting on the load cell will be obtained by a factor as a basis for calculating the forces that occur in the test model.

\subsection{The forces acting on the floater test model}

The forces acting on the floater are the same as the forces acting on ships that moving on the surface of the water at a certain speed. As a result of water shifting with the floater body, hydrodynamic forces include the drag force $(F x)$, side force $(F y)$, lift $(F z)$, and moments in the $x, y$, and $z$ directions to the point catch floater. Illustration of these styles can be seen in Fig. 3.

\section{Methodology}

To solve the problems faced, a method was made to facilitate the design of a measuring instrument 6 degrees of freedom of force and moment. In brief, this method can be seen in the flow chart in Fig. 4.

There are three main stages in the design of buildings measuring $6 \mathrm{DOF}$. The first is the design phase where at this stage it is necessary to know the range of force and moment measurements that will work on the measuring instrument, the determination, and design of a single load cell, the calculation of the weight of the material used. The second stage is the manufacturing stage of design. At this stage, a material for the spring load cell and a framework for the 6 DOF sensor is made. Single load cell calibration is also

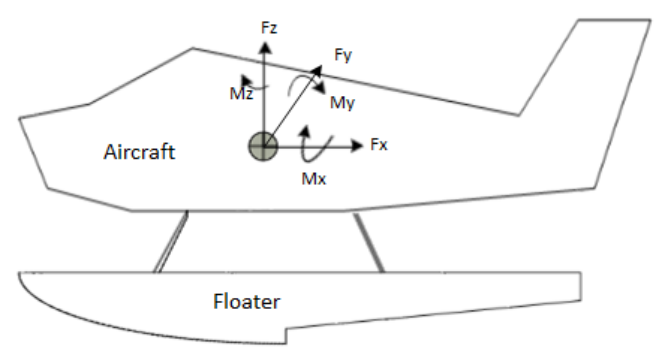

Figure 3. The styles in the floater test model [6] 
performed to determine the value of the single load cell calibration and repeatability performance. The last step was assembling the prototype 6 DOF sensor and testing the load force $F x, F y, F z$ to determine the accuracy of the signal and the measurement uncertainty that occurred.

Figure 5 shows how the measurement method to be used where 6 channels of 6 DOF sensors will be connected to signal conditioning which functions as a supply of voltage, signal output amplifier, and filter. The output of the signal condition is connected to the NI Data Acquisition which is connected to a PC for recording data and processing the output data from the 6 DOF sensor.

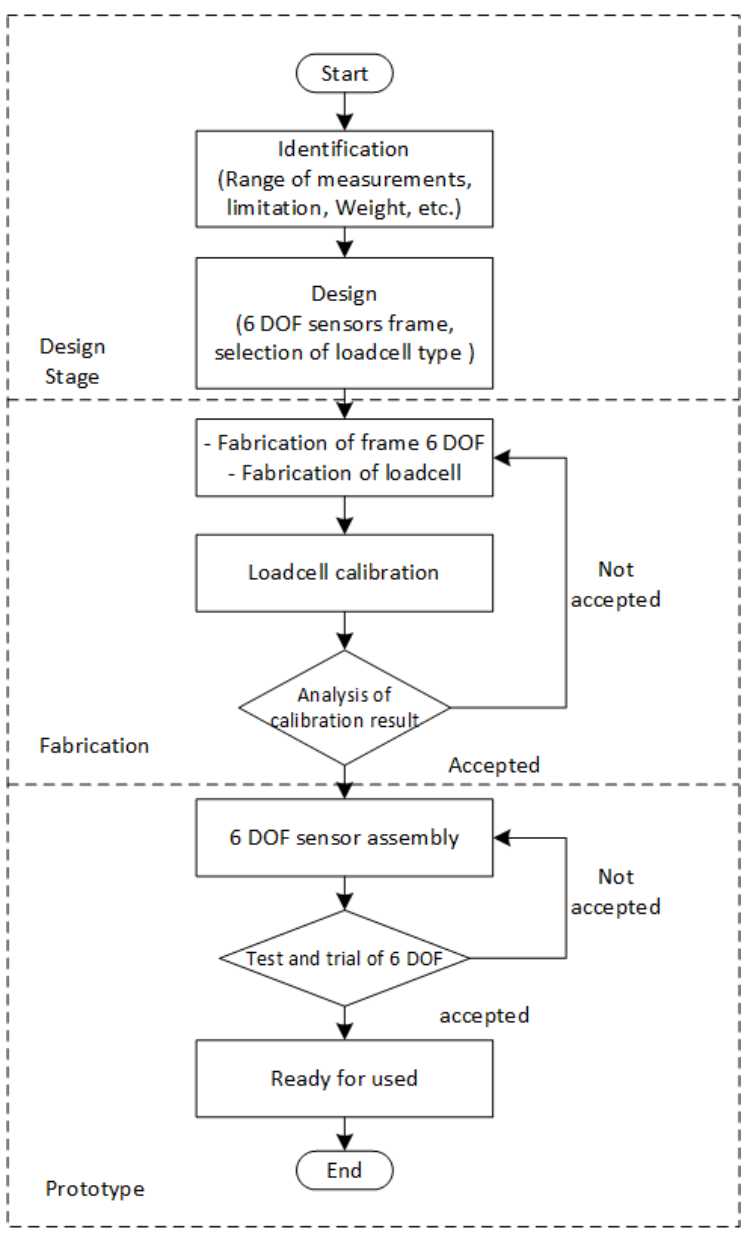

Figure 4. Methodology

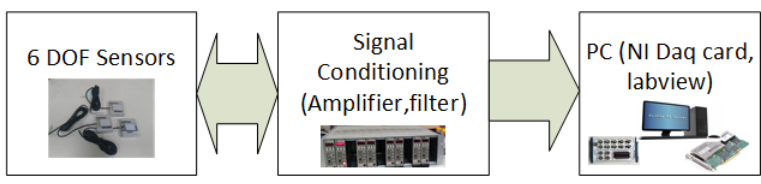

Figure 5. The Measurement method

\section{Results and Discussion}

\subsection{DOF sensor system design}

For the $6 \mathrm{DOF}$ load cell design, $6 \mathrm{~S}$ type load cells are needed. $\mathrm{S}$ type load cells can be made from aluminum alloy material as shown in Fig. 6. For dimensions adjusted to the design of the required load cell capacity. In the calculation of dimensions can be used software 'Transducers' made by Marin. Based on the results of the software for $100 \mathrm{~N}$ capacity obtained dimensions as in Table 1, the spring element dimensions for load cell type $\mathrm{S}$ with a capacity of $100 \mathrm{~N}$, so that if desired can be made according to the required capacity.

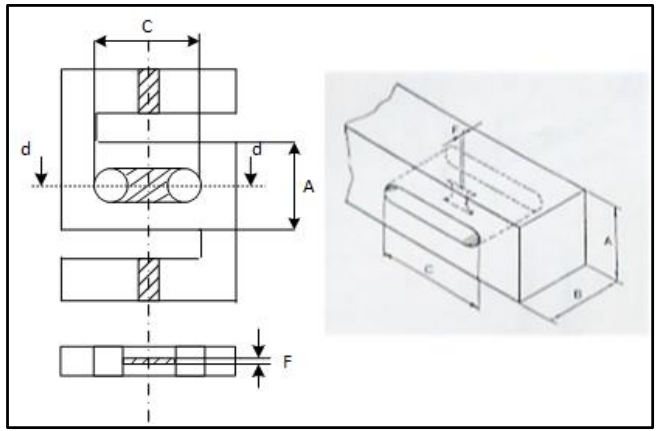

Figure 6. S Type of load cell (shear)

Table 1. The Output of transducers software for $100 \mathrm{~N}$ [7]

\begin{tabular}{|c|c|c|c|c|c|c|c|c|}
\hline \multicolumn{3}{|c|}{$\begin{array}{l}\text { MATERIAL } \\
\text { SENSITIVITY }\end{array}$} & \multicolumn{3}{|c|}{ MEASURING RANGE } & \multicolumn{3}{|c|}{$\begin{array}{l}\text { ALUMINUM } \\
\text { ELECTRICAL OUTPUT }\end{array}$} \\
\hline FX & 8.64 & $\mathrm{uR} / \mathrm{N}$ & FX & 116 & $\mathrm{~N}$ & FX & 17 & $\mathrm{uV} / \mathrm{V} / \mathrm{N}$ \\
\hline FY & 8.74 & $\mathrm{uR} / \mathrm{N}$ & FY & 114 & $\mathrm{~N}$ & FY & 17 & $\mathrm{uV} / \mathrm{V} / \mathrm{N}$ \\
\hline FZ & 1.3 & $\mathrm{uR} / \mathrm{N}$ & FZ & 797 & $\mathrm{~N}$ & FZ & 2 & $\mathrm{uV} / \mathrm{V} / \mathrm{N}$ \\
\hline MX & 1747 & $\mathrm{uR} / \mathrm{NM}$ & MX & 0.57 & NM & MX & 3511 & $\mathrm{uV} / \mathrm{V} / \mathrm{NM}$ \\
\hline MY & 343 & $\mathrm{uR} / \mathrm{NM}$ & MY & 2.91 & NM & MY & 690 & uV/V/NM \\
\hline MZ & 6217 & $\mathrm{uR} / \mathrm{NM}$ & $\mathrm{MZ}$ & 0.16 & NM & MZ & 12496 & $\mathrm{uV} / \mathrm{V} / \mathrm{NM}$ \\
\hline \multirow{2}{*}{\multicolumn{3}{|c|}{$\begin{array}{l}\text { MATERIAL MICRO STRAIN } \\
\text { (Z-AXIS IS LENGTH AXIS) }\end{array}$}} & \multirow{2}{*}{\multicolumn{5}{|c|}{$\begin{array}{l}\text { FULL BRIDGE STRAIN GAGE } \\
\text { INPUT DATA MILLIMETERS }\end{array}$}} & \\
\hline & & & & & & & & \\
\hline \multicolumn{3}{|c|}{ HEIGHT IN X-DIRECTION } & \multicolumn{3}{|c|}{$A=$} & \multicolumn{2}{|c|}{10.00} & MM \\
\hline \multirow{2}{*}{\multicolumn{3}{|c|}{ HEIGHT IN Y-DIRECTION }} & \multirow{2}{*}{\multicolumn{3}{|c|}{$\begin{array}{l}B= \\
C=\end{array}$}} & \multicolumn{2}{|c|}{5.00} & MM \\
\hline \multicolumn{2}{|c|}{ SLOT LENGTH } & & & & & \multicolumn{2}{|c|}{10.00} & MM \\
\hline \multicolumn{3}{|c|}{ THICKNESS SHEAR PLATE } & \multirow{2}{*}{\multicolumn{3}{|c|}{$\mathrm{F}=$}} & \multicolumn{2}{|c|}{2.00} & MM \\
\hline \multicolumn{3}{|c|}{ SLOT HEIGHT } & & & & \multicolumn{2}{|c|}{8.00} & MM \\
\hline
\end{tabular}

The design of manufacture is based on the numerical data of the force to be measured so we need a load cell with a capacity of 2 pieces of $50 \mathrm{~N}$ and 4 pieces of $100 \mathrm{~N}$. The capacity of $50 \mathrm{~N}$ is used as an $X$-axis load cell so that the maximum $F x$ force can be measured up to $100 \mathrm{~N}, F y 100 \mathrm{~N}$ is being $F Z$ to $300 \mathrm{~N}$. Because of the time and capacity considerations of $50 \mathrm{~N}$ and $100 \mathrm{~N}$ are widely available in the market, for the $\mathrm{S}$ type load cell, the manufacturer's Load cell "Dacell", Korean, with the UU model [8].

The calibration process is carried out by individually calibrating both the drag and press of each type S load cell used. Calibration is carried out by giving a load in stages, as shown in Fig. 7, the resulting output is measured so that the calibration factor is known that shows the relationship between the load or force $(\mathrm{kg})$ and the output voltage (volts). 

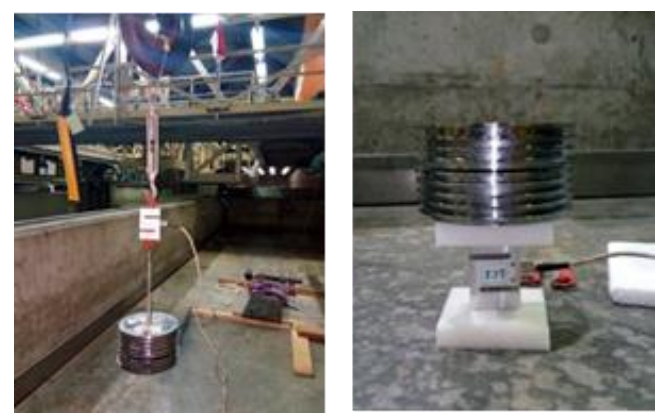

Figure 7. Pull and push calibration of single load cell



Figure 8. Calibration output of S1 load cell

An example of a calibration graph output can be seen in Fig. 8. The $\mathrm{x}$-axis shows the input load $(\mathrm{kg})$ and the $y$-axis is the resulting output (volts) so the trend line graph is known as a multiplier factor for the output signal load cell amplifier that read by the data acquisition system.

The mechanical configuration of the 6 DOF sensor system and the design of the 6 DOF sensor frame can be seen in Fig. 9. In Fig. 9 (a). There are 6 load cells arranged in such a way that a $6 \mathrm{DOF}$ ( 6 degree of freedom) sensor is formed. On the 6 DOF sensor, there are six load cells S1 - S6 which are used to measure the magnitude of the force $F z, F y, F z$, and moments $M x, M y, M z$. Figure 9 (b) shows the 6 DOF sensor circuit in 3 dimensions, how the placement of load cells S1 - S6 refers to Fig. 9 (a). From the series of Fig. 9 (a), it is known that to measure the Fx force 2 load cells are used, $F y 1$ load cell and $F z \quad 3$ load cells are used. From the



Figure 9. (a) Configuration of 6 DOF (b) Frame design of 6 DOF measurement results of S1 - S6 load cell, then the magnitude of force and moment can be determined by the formula:

$$
\begin{aligned}
& F x=S 1+S 2 \\
& F y=S 3 \\
& F z=S 4+S 5+S 6 \\
& M x=\frac{1}{2} c(S 6-S 5) \\
& M y=\frac{1}{2} b(S 4-S 5-S 6) \\
& M z=\frac{1}{2} a(S 1+S 2)
\end{aligned}
$$

\subsection{Design measurement model test}

To be able to know the magnitudes of the forces and moments caused by the hydrodynamic forces on the amphibious plane floater, the measurement design is made as shown in Fig. 10. In Fig. 10 it is shown that the transformation of the measured force and moment from the 6 DOF sensor axis to the specified measuring point for example, from A to B.

In Fig. 10, the magnitude of the measured force and moment is at point A which is so that it will be given the notation Fxa, Fya, Fza, and Mxa, Mya, Mza. The results of the measured quantities need to be transformed to the desired center point in this case at point $\mathrm{B}$. If the distance between points $A$ and $B$ is equal to $m$, the formula for force and moment transformation is obtained as follows:

$$
\begin{aligned}
& F x b=F x a \\
& F y b=F y a \\
& F z b=F z a \\
& M x b=M x a+F y a \cdot m \\
& M y b=M y a+F x a \cdot m \\
& M z b=M z a
\end{aligned}
$$

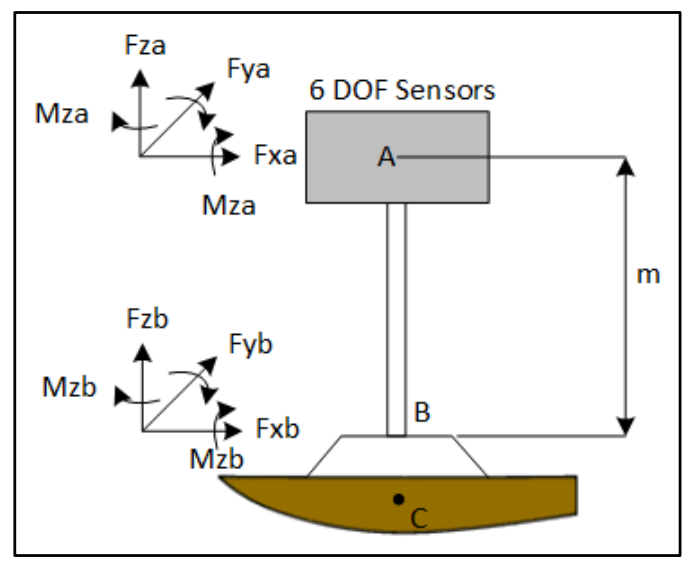

Figure 10. Transformation from point A to B 


\subsection{Test and measurement results}

The model testing was carried out on the floater model which was connected with the 6 DOF measuring device as the measurement design of Figure 10, while the shape of the aircraft was not modeled because the fuselage was not immersed in water. The floater model is made on a certain scale by considering the maximum speed of the tug train in the Towing Tank. In the floater test, the model is pulled with a certain speed, and with the measuring instrument, 6 DOF measured the forces that work so that the influence of hydrodynamic forces on the floater model is known.

Before testing, the measurement is carried out by weighing the measuring instrument 6 DOF of 1300 gr towards the $Z$-axis $(F z)$. The measurement results can be seen in Fig. 11. From Fig. 11 it can be seen that the dominant values are found in the outputs of S4, S5, and S6 as constituents of the $F Z$ style [9]. By adding the three in which S4 (345 gr), S5 (387 gr), and S6 (550 gr) the average measured force is $1,282 \mathrm{gr}$, so there is a difference of $18 / 1300$ or $1.38 \%$.

Model testing is done after testing the DOF 6 gauge and testing the road to find out the performance of the model and the measuring instrument, the floater test model is pulled in several speed points with variations of the draft on the model.

In Fig. 12, the output of one of the seaplane floater models is shown. In the picture, there are 7 channels wherein channel 1 shows the test speed of the floater model, channel $2(F x)$, channel $3(F y)$, channel $4(F z)$, channel $5(M x)$, channel $6(M y)$, and channel $7(M z)$. These values are obtained by processing the output signal according to the formula [13-18].

On the test graph in Fig. 12, when the condition of the test speed has stabilized on channel $1(\mathrm{~V})$ it is known that the average test speed is $9.19 \mathrm{~m} / \mathrm{s}$. For the magnitude of the force and moment, there are fluctuations in the measurement results that can be caused by the vibration of the floater when pulled. From the Fig. 12, we get the average values of $F x$ $(336.21 \mathrm{~kg}), F y(6.40 \mathrm{~kg}), F z(583.43 \mathrm{~kg}), M x(200.64 \mathrm{~kg}$ meter), $M y(1013.85 \mathrm{~kg}$ meter) and $M z$ (78.12 kg meter) where this value has been multiplied by the scale factor of the model test.

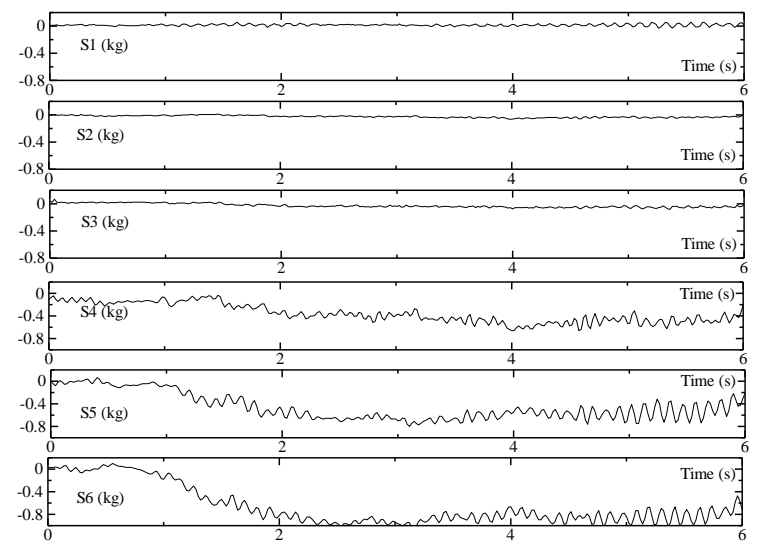

Figure 11. Load test of $F z$ at 6 DOF transducers



Figure 12. Example force and moment result from the output testing with $6 \mathrm{DOF}$

\section{Conclusion}

From the design of the 6 DOF transducer for the measurement of the hydrodynamic forces of the seaplane floater, it can be concluded that:

- $6 \mathrm{DOF}$ transducer can be made from $6 \mathrm{~S}$ type load cells which are arranged in such a way that the direction $\mathrm{x}, \mathrm{y}$, and $\mathrm{z}$, so that it can be used to measure the force $F x, F y$, $F z, M x, M y$ and $M z$.

- Load cell calibration and calibration factor values are very important to know correctly because this will affect the accuracy of the measurement results. In testing the measurement of the $\mathrm{Fz}$ force, an error of $1.38 \%$ is obtained so that the sensor is proper to use.

- In testing the hydrodynamic forces using a 6 DOF transducer it is necessary to transform the force and moment produced by the sensor at the desired point, so the distance between that point and the center of the 6 DOF sensor needs to be known.

- To get high accuracy, the capacity of the type S load cell must be adjusted according to the needs according to the prediction of the magnitude of the force to be measured.

\section{References}

[1] M. M. Lubis, "Analisis Aerodinamika Airfoil Naca 2412 Pada Sayap Pesawat Model Tipe Glider Dengan Menggunakan Software Berbasis Computional Fluid Dinamic Untuk Memperoleh Gaya Angkat Maksimum," J. e-Dinamis, vol. 2, no. 2, pp. 23-33, 2012.

[2] J. Ma and A. Song, "Fast Estimation of Strains for Cross-Beams SixAxis Force/Torque Sensors by Mechanical Modeling," Sensors Actuators A. Phys, vol. 13, pp. 6669-6686, 2013.

[3] D. F. Rendra, W. B. Setiawan, and R. Mareta, "Aplikasi Pengukur 3 Derajat Kebebasan Gaya Aerodinamika Pada Water Tunnel," J. Sains dan Teknol., vol. 6, no. 2, pp. 258-267, 2017.

[4] S. A. Liu and H. L. Tzo, "A Novel Six-component Force Sensor of Good Measurement Isotropy and Sensitivities," Sensors Actuators A 100, pp. 223-230, 2002.

[5] J. Vaughan, Application of B\&K Equipment to Strain Measurement. Copenhagen: Bruel \& Kjaer, 1975. 
[6] K. Ito, T. Daenen, Y. Hirakawax, T. Hirayama, and T. Sakurai, "Longitudinal Stability Augmentation of Seaplanes in Planing," $J$. Aircr., vol. 53, no. 3, pp. 1332-1342, 2016.

[7] “Marine Transducers Software," 2008.
[8] "Load Cell." [Online]. Available: http://www.dacell.com/en/load cell/show/view/cno/10/pno/40/page/3/id/748. [Accessed: 22-Nov2019]. 